
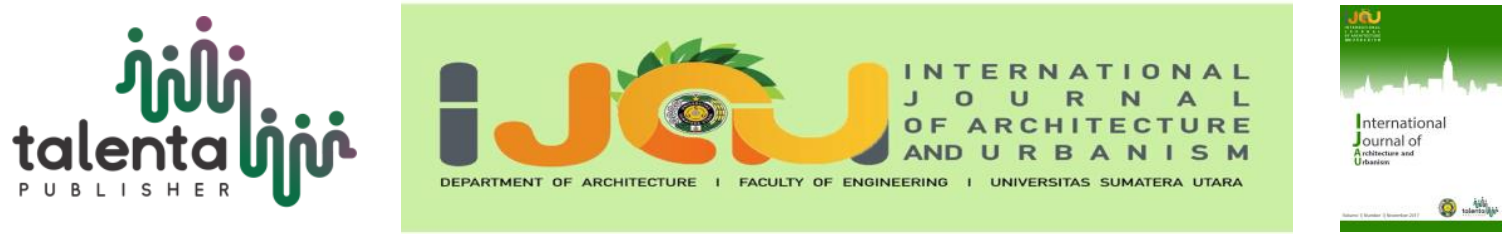

\title{
Revitalization of Pekan Labuhan Traditional Market (Behavioral Architecture)
}

\author{
Devin Defriza Harisdani ${ }^{*}$, M. A.F. S. Hadintha ${ }^{I}$ \\ ${ }^{1}$ Department of Architecture, Universitas Sumatera Utara, Medan, Indonesia
}

\begin{abstract}
Business opportunities and challenges in the economic sector are underway in the country, including in Medan Labuhan. Many regions build their territory by making public spaces such as traditional markets. Nowadays, there is a change of consumer behavior toward the traditional market so; its positions are replaced by the modern markets. With the revitalization of Pekan Labuhan traditional market that carries the theme of behavioral architecture is expected to restore the function of the traditional market as a place of selling and purchasing transaction and increasing competitiveness to the modern market. With the achievement of this issue will increase consumer interest to shop in Pekan Labuhan traditional market which then gives a good impact on the economic stability of Medan Labuhan.
\end{abstract}

Keyword: revitalization, market, increase, behavioral

\section{Introduction}

Business opportunities and challenges in the economic sector are underway in the country, including Medan Labuhan. Many regions build their territory by making public spaces such as traditional markets. Nowadays, there is a change of consumer behavior toward the traditional market, so its positions are replaced by the modern markets, the convenience that modern markets offer makes people's interest in traditional markets decline.

Traditional markets have a role in increasing income and employment. Behind the role is a necessary effort to increase the competitiveness of traditional markets that are identical with a dirty trading location and traffic jams. Descriptions of traditional markets that decline in function are known from the dominance of adult visitors. In fact, the ideal market should be able to attract visitors from all age groups considering the role of the market as a place of sale and purchase transactions.

With the revitalization of Pekan Labuhan traditional market that carries the theme of behavioral architecture is expected to provide specific design solutions. Design focus on the analysis of

*Corresponding author at: Department of Architecture, Faculty of Engineering, Universitas Sumatera Utara,

Jalan Perpustakaan Gedung J07, Medan 20155, Indonesia

E-mail address: devin.defriza@ usu.ac.id 
market user behavior taking into the daily market activities. Thus, Pekan Labuhan traditional market can be a market that prioritizes the convenience of consumers. And in the end, this revitalization increases consumer interest to shop in traditional markets which then gives a good impact to the economic stability of Medan Labuhan.

\section{Literature Review}

Revitalization is an effort to improve the vitality (life) of urban areas through improvement and renewal of environmental quality, taking into account the socio-cultural aspects and characteristics of the region [3]. Revitalization is an attempt to rebuild a region or part of an area that was once vital or alive but suffered a setback or degradation [1].

According to Regulation of the Minister of Trade, "PERMENDAG 2014. A market is a certain Area where buyers and sellers meet both directly and indirectly, by buying and selling various types of consumer goods through bargaining.

Behavioral architecture is the architecture which in its application always include the behavioral considerations in designing behavioral link with architecture design (as physical environment) that architecture design can become a facilitator of behavior or vice versa as the barrier of behavior [2].

\section{Methodology}

The reference for design site selection reference is based on the Building and Environmental Management Plan of Medan Labuhan Pecinanan Area 2010-2030 ('RTBL). Based on the structure of the area, it is explained that the design location is in the area functioned as the trade and industrial activities, health, and transportation service center.

The assessment stages in site selection and process design on the Revitalization of Pekan Labuhan Traditional Market project can be elaborated through these several stages. Site data collection stage which refers to the (RTBL), which is based on the structure of the region that the location will be designed is a residential area with low population density medium that is not well ordered. Pre-design stage in the form of ideas to revitalize the traditional market of Pekan Labuhan which has decreased the competitiveness of the modern market so that it impacts the economy of Pekan Labuhan.

Design analysis stage by the information and data that support both of architectural and nonarchitectural through various libraries and media as a consideration in solving problems which including basic concept, site plan design, circulation concept, mass composition concept, plan

\footnotetext{
* PERMENDAG (Peraturan Menteri Perdagangan) = Regulation of Trade Ministry

$\uparrow$ RTBL (Rencana Tata Bangunan dan Lingkungan) $=$ Regulation of Building and Environment
} 
concept, structure, and utility concept. The final stages of the development of the design idea will be poured into the detail of the plan, section, and 3D impression.

\section{Result and Discussion}

The purpose of this Revitalization of Pekan Labuhan traditional market is to improve the competitiveness and function of traditional market as a place of sale and purchasing transaction that decreasing consumer. This revitalization also aims to eliminate the impression of a traditional market is a dirty place, that will increase consumers which then gives a good impact on the economic stability of Medan Labuhan. The location of the design is located in Medan Labuhan sub-district of Pekan Labuhan and the densely populated slums. The site of this project has an overall area of about 2.6 hectares.

\subsection{Basic Concept}

Changes in consumer behavior are the decline in interest in shopping in the Traditional Market became the main focus of the basic concept of design. The impression of a dirty and chaotic traditional market becomes the main reason consumers do not shop at the traditional market.

Through the application of the concept of behavioral architecture in design, the design on this market refers to the consumer in the traditional market that aims to provide convenience shopping at traditional market. Some forms of behavioral theme into the design of Pekan Labuhan traditional market such as wide corridor, many access to exit and enter the building and grouping of similar product aims to provide a new look and reflection of a Traditional Market.

\subsection{Exterior/Siteplan Concept}

Site spatial arrangement oriented by site processing as a parking area and circulation area. The parking area is split up in several places according to the entrance access which reduces the commotion to the market. There are elements forming outer space on the design of this market, such as Market Building, Management Office, Garbage Disposal, Transportation Shelter, Parking Area and Green Area (Figure 1).

The concept of achievement in the design of Pasar Labuhan Revitalization is to be accessible in every direction; the entrance is on each side of the site to facilitate the users to the site, so it will attract more visitors to shop. Car Entrance, Drop Off and main pedestrian entrance are accessible via Yos Sudarso Main Street, while two Wheel access is accessible via Syahbudin Yatim Street. 


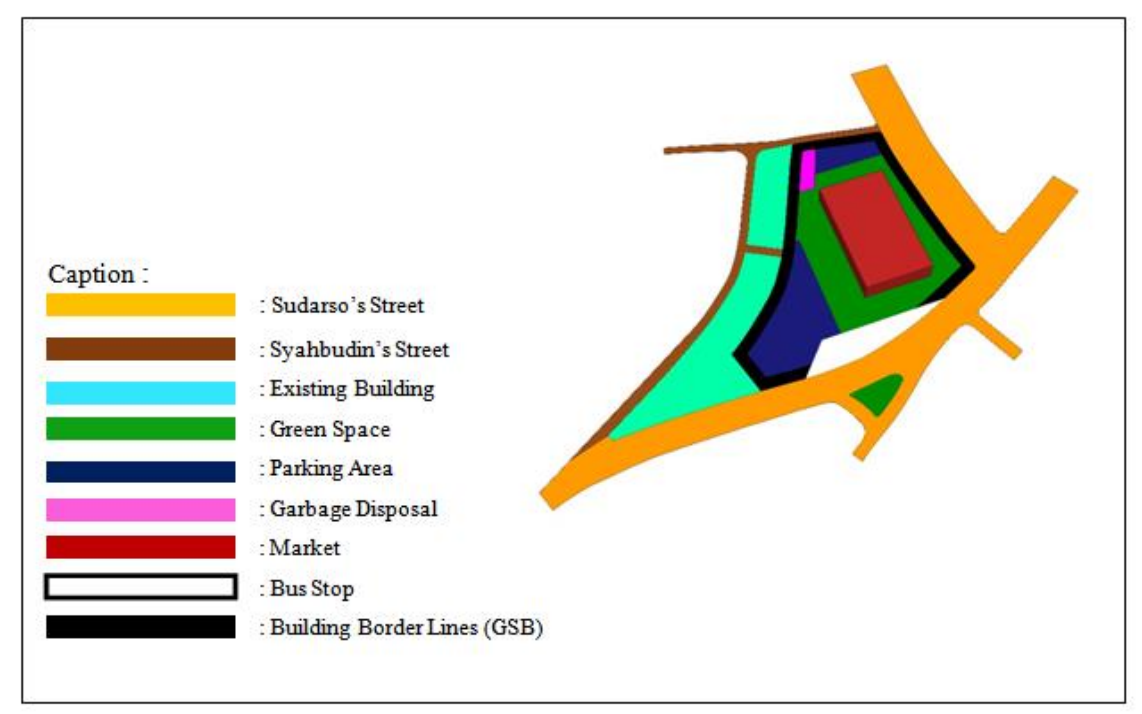

Figure 1. Exterior/Siteplan Design

\subsection{Circulation Concept}

The concept of achievement in the design of this market is accessible in every direction, the entrance is on each side of the site to facilitate the users to enter the site, so it will attract more visitors to shop. Car Entrance, Drop Off and main pedestrian entrance are accessible via Sudarso's street, while two-wheel access can be accessed via Syahbudin's street (Figure 2). Design concept Parking in the design area Revitalisasi Pasar Rakyat Pekan Labuhan is secure parking that is a security system by using a ticket so that the security of the vehicle will be more easily organized. For car parking areas use trees and plants as a buffer of sunlight while on Motorcycle parking area using a roof canopy.

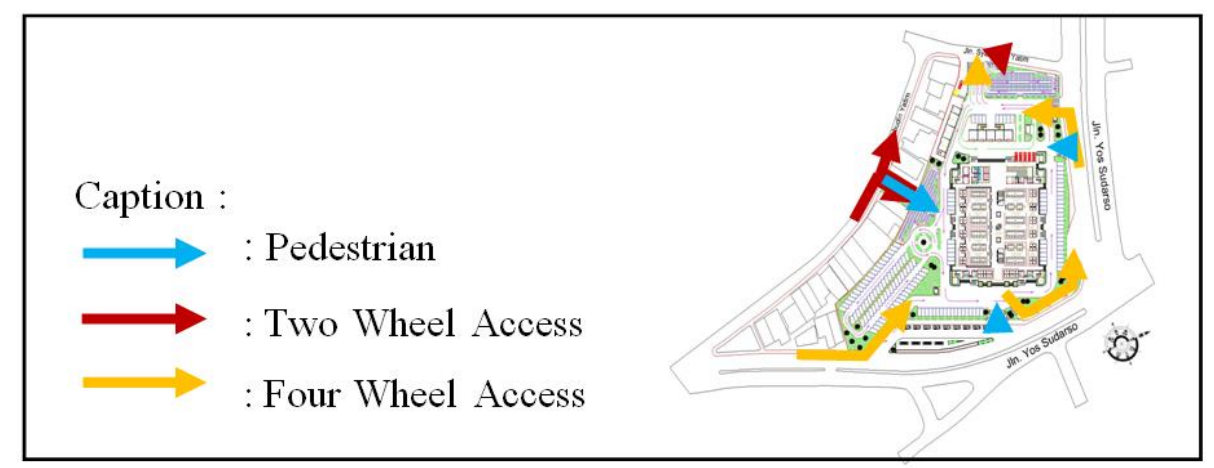

Figure 2. Circulation Concept

\subsection{Mass Composition Concept}

Building concept in this design takes the form of a rectangle, the advantages of this form is the effectiveness the division of market spaces, consideration of dense activity in the market, the shape of the building is given open aperture that serves as natural airing system and user access (Figure 3). The aesthetics of the building in the design of Pasar Rakyat Market Revitalization Pekan Labuhan on the facade of the building, namely the design of access in and out which forms the rhythm of the building. 


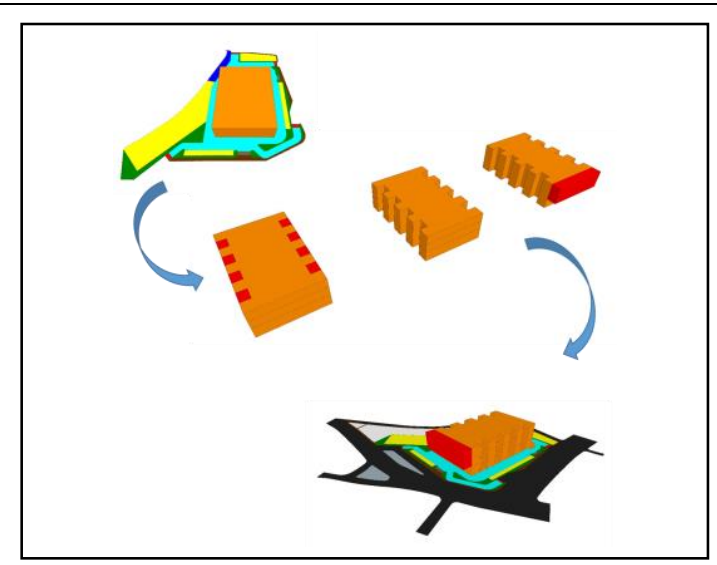

Figure 3. Mass Composition Concept

\subsection{Concept of Inner Space Permit}

This market consists of 3 Floors and Roof Top, with the concept of Floor 1 flooring is Wet Area, 2nd and 3rd Floor is Dry Area and Roof Top as Service Area. Laying the Wet Area on the 1st floor aims to make cleaning activities easier, wet areas consisting of fish trade area, meat and vegetables have the garbage that is the center of attention, by being placed on the ground floor of waste from the Wet Area going directly to the Disposal Area. The wet area is also the main destination for consumers to shop to the market, so it is suitable on the ground floor of the building, while on the second floor is dry area and food court and on the third floor is the area of fashion and jewelry (Figure 4).

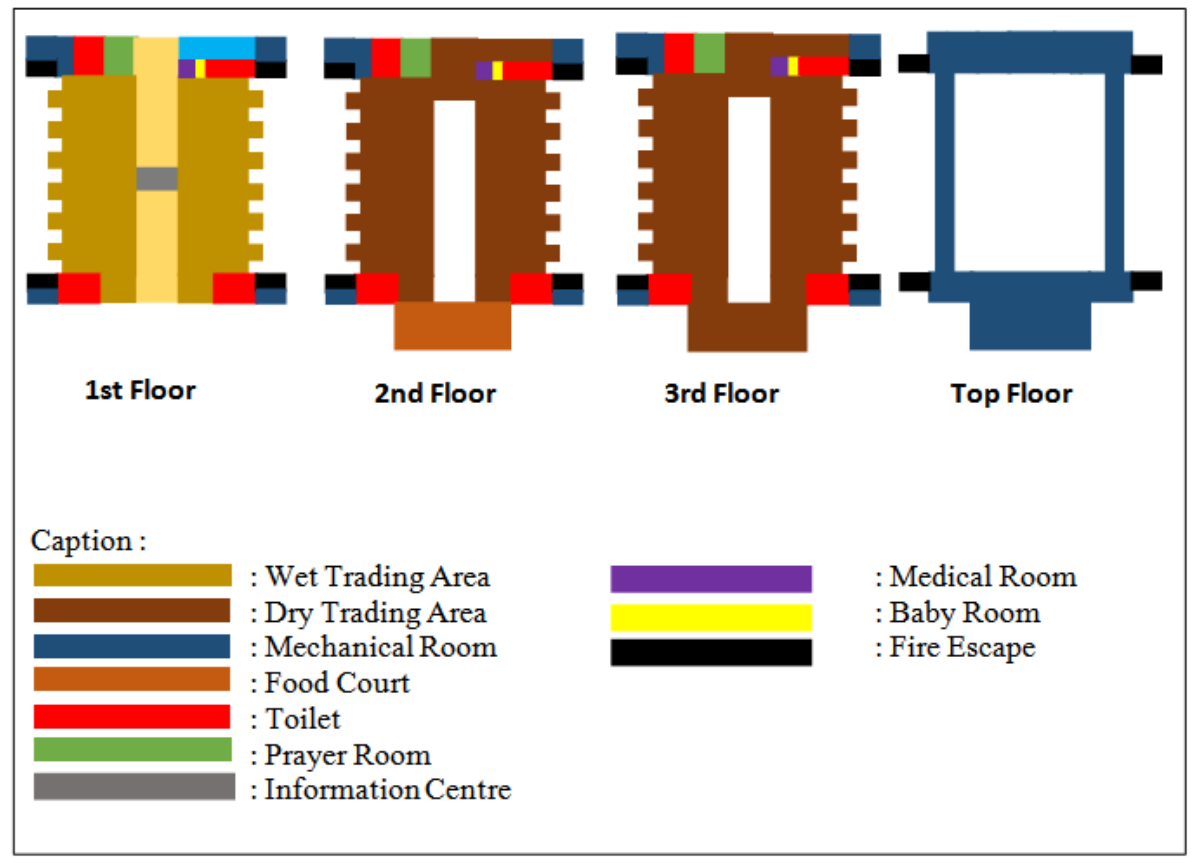

Figure 4. Concept of Inner Space Permit

\subsection{Structure Concept}

This market uses Rigid Frame structure system where the structure is more focused on the grid system that supports the function of the room inside. The choice of Rigid Frame structure 
system is due to Functionally this structure facilitates the placement of stalls and market stalls and circulation. Make it easy to open aperture that serves as a natural airing system. To optimize the burden of expenditure effectively (Figure 5).

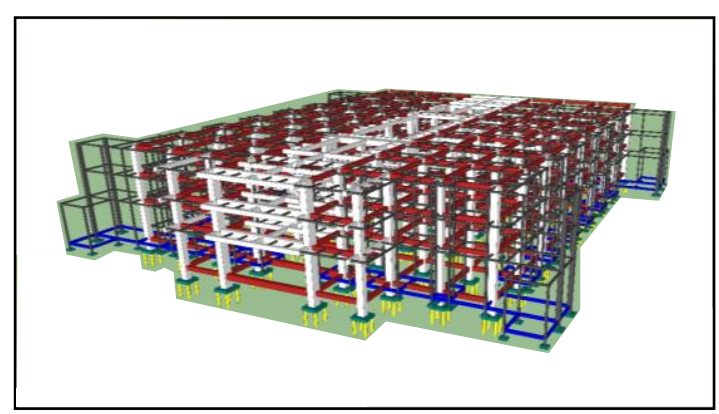

Figure 5. Structure Concepts

\subsection{Utility Concept}

Utility concept in this building consists of clean water supply system, dirty water distribution, and electrical system; the utility concept is separate from the main building of the market so that the activities in the utility room are not disturbed by the market users. The source of clean water supply in this building comes from a water supply company that is housed inside the groundwater tank and then pumped to rooftop tank so that it can be distributed to all buildings, (Figure 6). The concept of dirty water distribution using filtered tanks to separate the waste, then dirty water will be forwarded to the city drainage (Figure 7). The Concept of Electrical Systems of a building using a transformer as an energy collector from State Electricity Company will then be forwarded to the entire building through a control panel (Figure 8).

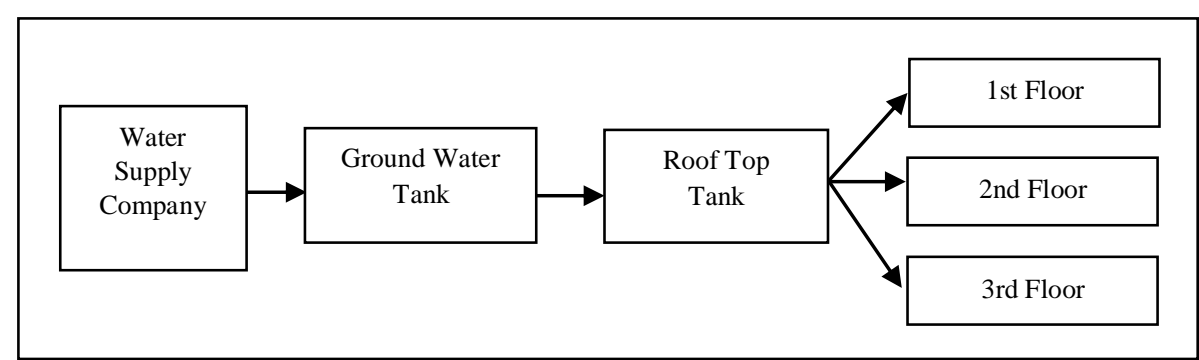

Figure 6. The Concept of Clean Water Supply System

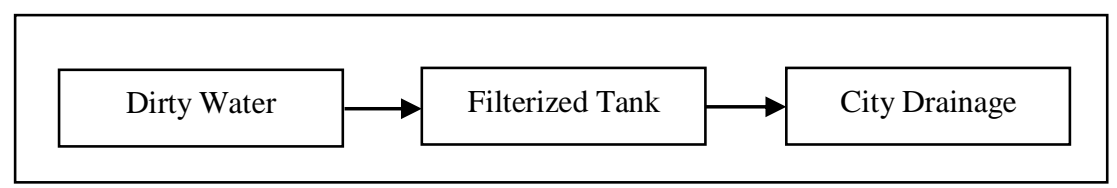

Figure 7. Concept of Dirty Water Distribution 


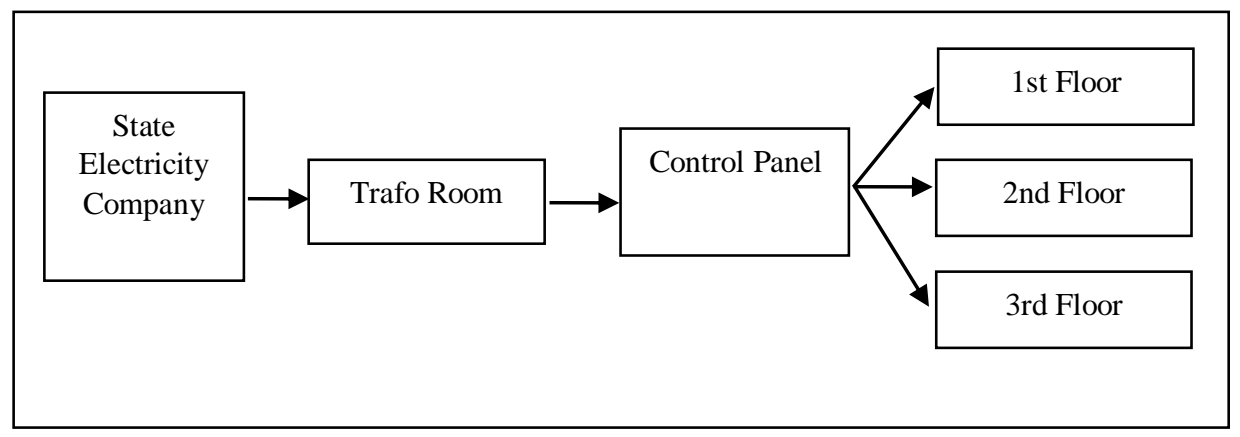

Figure 8. The Concept of Electrical Systems

\subsection{Design Concept}

Based on the concept review described in the previous chapter, this research provides the results of the design decisions. Design The market has good air circulation, cultivates outdoor areas into parking lots, provides a clean market atmosphere with a viable utility system, ease of access for users to shop in the market, vast buying and selling areas for user activity.

This market revitalization also includes market building infrastructure, with the aim to provide comfort and good service to consumers, so that the impression of a dirty and dirty market can be lost to change into a comfortable net market, the Design of Market Revitalization Pekan Labuhan theme behavioral architecture, where each design on this design refers to user behavior, it also aims to provide convenience for consumers to shop so that traditional market can be the main choice of consumers to shop and eventually the traditional market can return to compete with a modern market. The design is realized in the Site Plan, Ground Plan, Section, Structure Plan, Exterior and Interior Views (Figure 9- 12).

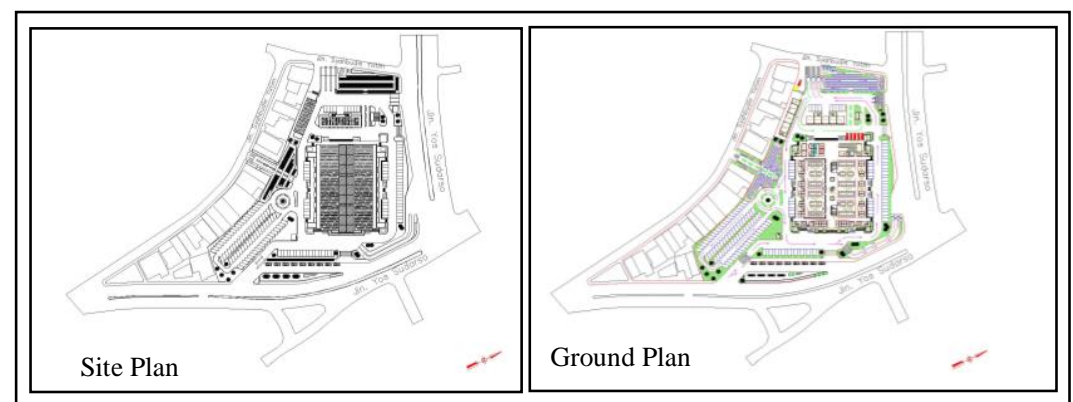

Figure 9. Site Plan and Ground Plan 


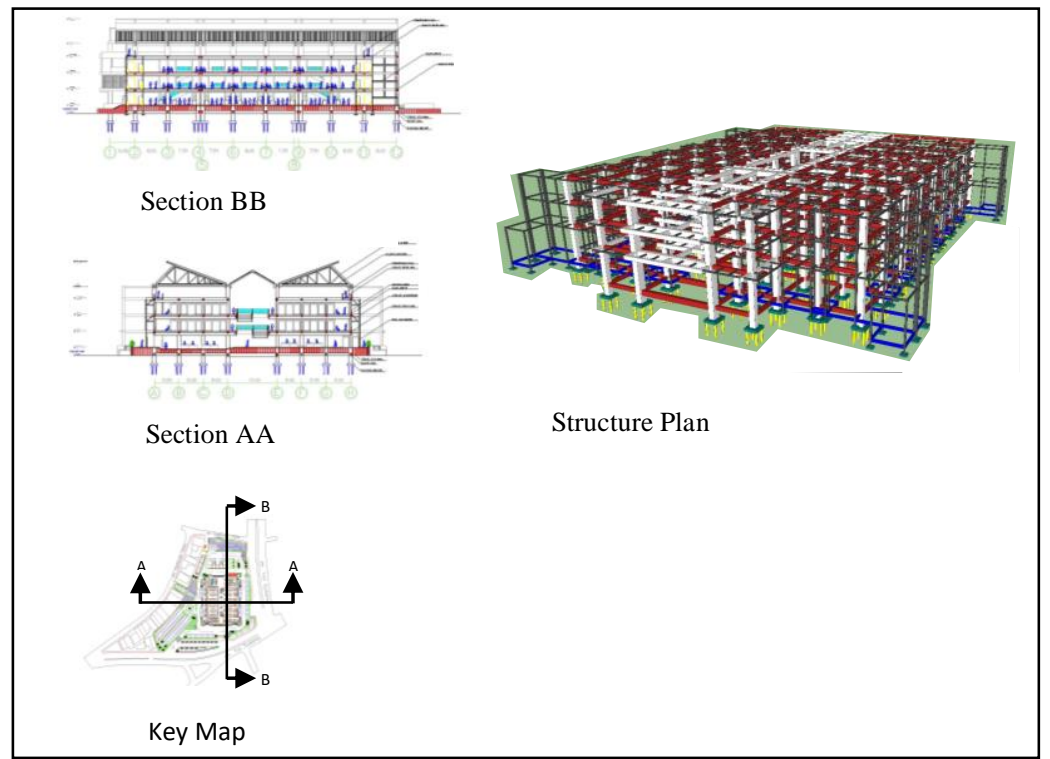

Figure 10. Section and Structure Plan

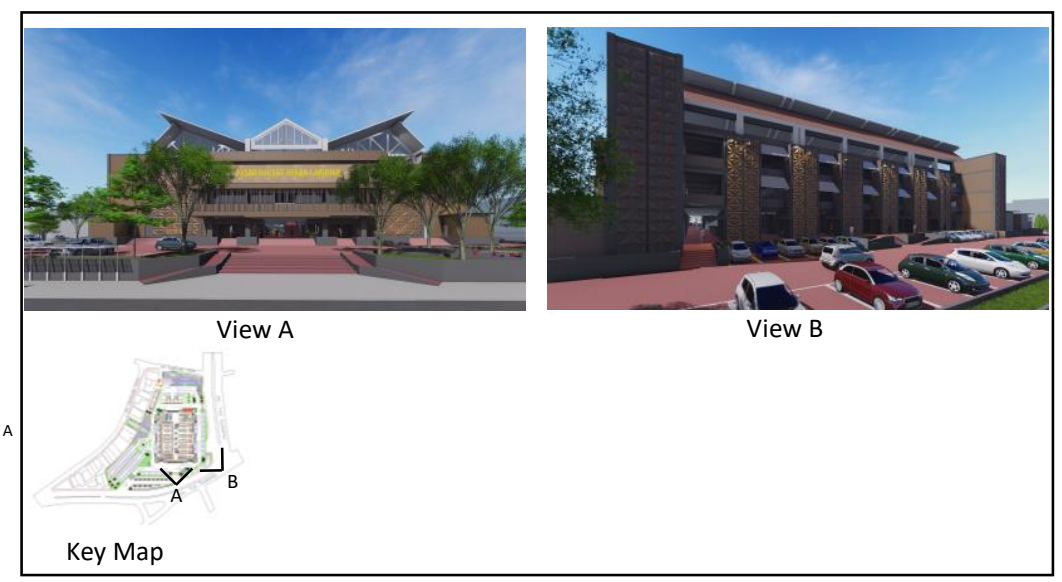

Figure 11. Exterior View

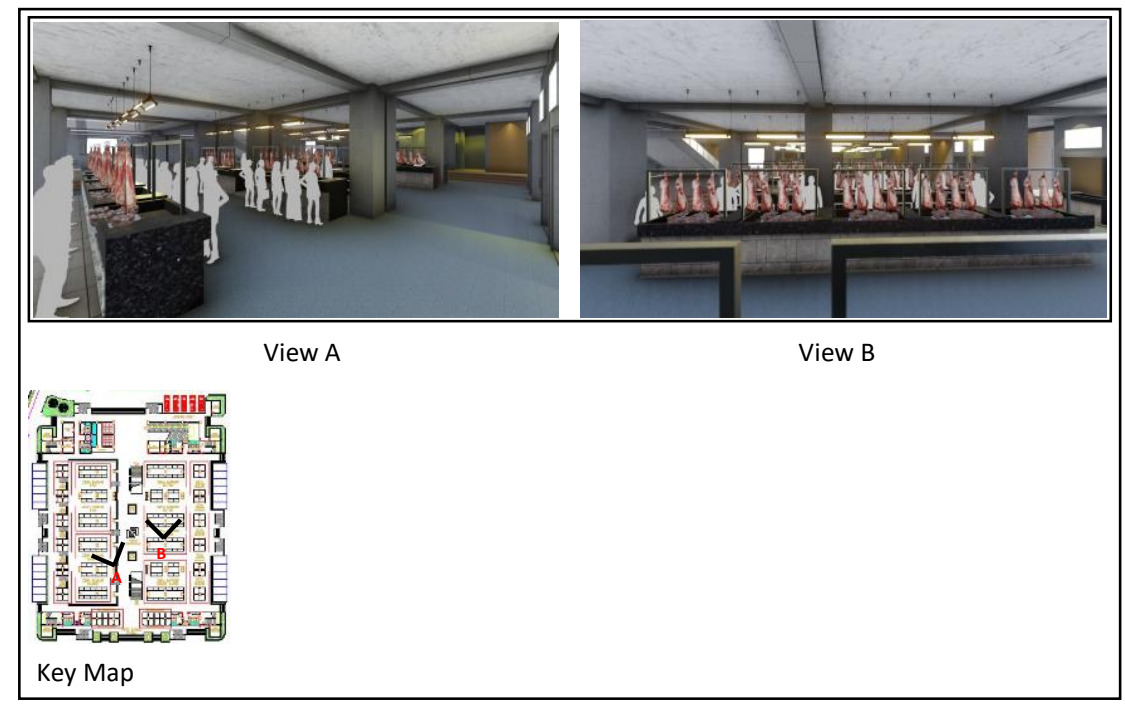

Figure 12. Interior View 


\section{Conclusion}

To increase the number of visitors, this market is designed to prioritize the convenience of visitors by arranging the trade area and conducting the inner space on similar merchandise to facilitate the user and prevent crowded on the market, the arrangement of vehicle circulation and parking area are also aims to facilitate the user so that increase the number of visitors Pekan Labuhan traditional market. The revitalization of this traditional market also includes the infrastructure of market buildings, with the aim of providing comfort and good service to consumers that eliminate the impression which traditional market is a dirty place. Design of this market takes the theme of behavioral architecture, where every design in this building refers to the behavior of market users. So, this market will function effectively in accommodating of buying and selling activities.

\section{Acknowledgment}

This research is part of the requirement to obtain a bachelor's degree in Architecture Department, Universitas Sumatera Utara.

\section{REFERENCES}

[1] M. Danisworo. Kesinambungan dan Perubahan dalam Konservasi Kota, dalam Monumen dan Situs Indonesia. 1999.

[2] L. J. Marcella. Arsitektur dan perilaku manusia. Jakarta: PT. Grasindo, 2004.

[3] W. Martohusurno and R. S. P. D. P . Kawasan. Revitalisasi, Sebuah Pendekatan Dalam Peremajaan Kawasan. 2008. 